\title{
Is there any place for a transobturator approach for minisling surgery?
}

\author{
Ahmet Akin Sivaslioglu \\ Received: 13 March 2013 / Accepted: 4 June 2013 / Published online: 19 June 2013 \\ (C) The International Urogynecological Association 2013
}

Dear Editor,

I read with interest Naumann et al's. article on Ajust in the International Urogynecology Journal [1]. At 2 years, 42/51 patients $(82.4 \%)$ had their continence fully restored.

I write to draw readers' attention to our 5-year randomized controlled trial study: "Tissue Fixation System (TFS) Minisling vs Transobturator Tape (TOT)" $(n=80)$, as reported in 2012 in the Journal of Urology [2]. The TFS comprises a polypropylene, macroporous, monofilament mesh strip that has polypropylene soft-tissue anchors on each side, with a one-way tensioning system. The anchors were implanted retropubically, and the TOT was inserted by an outside/in technique. At 5 years, the objective cure rates for TFS and TOT were $83 \%$ and $75 \%$, respectively $(p=0.029)$. Mesh extrusion rate was low: one for each group. Nine from the TOT group (23\%) reported groin pain postoperatively. There were no reports of pain from the TFS group.

It is interesting to note that patients with intrinsic sphincter deficiency (ISD) $\left(<20 \mathrm{~cm} \mathrm{H}_{2} \mathrm{O}\right.$ on profilometry) were excluded from Naumann et al.'s study [1]. In his 2005 study $(n=36)$, the first minisling reported in the literature, Petros [3] reported that $9 / 10$ patients with ISD were $100 \%$ dry postop- eratively and one was $80 \%$ improved. All results reported included the learning curve.

The TFS is a tensioned sling, so it can be very precisely tensioned after implantation. It is also retropubic. Given the high cure rates for ISD reported with the retropubic TFS, the question needed to be asked is: "Is there any place for a transobturator approach for minisling surgery"?

Conflict of interest None.

\section{References}

1. Naumann G, Hagemeier T, Zachmann S et al (2013) Long-term outcomes of the Ajust ${ }^{\circledR}$ adjustable single-incision sling for the treatment of stress urinary incontinence. Int Urogynecol J 24(2):231-239

2. Sivaslioglu AA, Unlubilgin E, Aydogmus S et al (2012) A prospective randomized controlled trial of the transobturator tape and tissue fixation mini-sling in patients with stress urinary incontinence: 5-year results. J Urol 188:194-199

3. Petros PEP, Richardson PA (2005) The midurethral TFS sling- a 'micro-method' for cure of stress incontinence- preliminary report. ANZJOG 45:372-375
A. A. Sivaslioglu $(\bowtie)$

Atatürk Training and Research Hospital, Gynecology and Obstetrics Unit, İzmir Katip Çelebi University, Seferihisar caddesi, 2730. sokak Ege Park Konakları No:53

Yelki/Güzelbahçe, İzmir, Turkey

e-mail: akinsivaslioglu@gmail.com 